\title{
Physico-Chemical and Microbiological Characterization of Soils Laden with Tannery Effluents in Sokoto, Nigeria.
}

\author{
* A.B. Rabah and M.L. Ibrahim \\ Department of Microbiology, Usmanu Danfodiyo University, Sokoto. \\ *Correspondence author: abrabah2003@yahoo.com.sg
}

\begin{abstract}
Changes in microbial community content as well as physico-chemical properties of soil contaminated with tannery effluents in Sokoto metropolis were determined using standard procedures. The results showed that the soil sample contained a variety of microorganisms which include Bacillus cereus, Bacillus subtilis, Pseudomonas aeroginosa, Proteus mirabilis, Serratia marcensces, Escherichia coli, Streptococcus pyogenes, Klebsiella pneumoniae, Aspergillus niger, Aspergillus flavus, Aspergillus fumigatus, Penicillium notatum, Mucor pusillus as well as Fusarium sporotrichioides. It also revealed high counts of bacteria and fungi in all the sampling sites. The viable count of bacteria was in the range of $8.60 \pm 1.80-8.70 \pm 0.52 \times 10^{5} \mathrm{cfu} / \mathrm{g}$ while that of fungi was $1.70 \pm 0.30-2.0 \pm 0.10 \times 10^{4} \mathrm{cfu} / \mathrm{g}$. Similarly, it revealed high levels of sulphide $(0.35-0.44 \mathrm{mg} / \mathrm{g})$, ammonia $(0.40-0.60 \mathrm{mg} / \mathrm{g})$, and chromium $(0.20-0.26 \mathrm{mg} / \mathrm{g})$ in all the sampling sites. These levels exceeded the tolerable levels set by the Federal Ministry of Environment. The presence of these microorganisms and chemical substances pose a potential threat to the local inhabitants of these areas.
\end{abstract}

KEYWORDS: Physico-chemical, Microbiological, Soil, Tannery, Effluent, Sokoto

\section{INTRODUCTION}

Tannery effluents refer to the wastewater resulting from the process of converting skins and hides into leather. The process of tanning requires large volume of water, which is used to either cleanse the hides and skins, or to serve as a medium of interaction between the hides and skin (Imamulhaqq, 1998). During the tanning process, large amount of effluents are discharged into the surrounding soil as well as water sources. These effluents may contain a variety of chemicals that are used in the tanning process such as sodium sulphate, chromium sulphate, non-ionic wetting agents and may accumulate in the immediate environments of the tannery (Tudunwada et al., 2007). The high sulphide content of tannery effluents apart from being toxic to humans, may also pose serious odour problems when discharge into the environment. Chromium content of the effluent may pose great danger to humans in as much as it is toxic to humans from a level as low as $0.1 \mathrm{mg} / 1$ (Tudunwada et al., 2007).
Also when the effluents are not properly managed, many pathogenic microorganisms in the effluents may predispose the inhabitants to serious health hazards (Ogbonna et al., 2004). It may also deplete the dissolved oxygen of water bodies thereby affecting the aquatic ecosystems. The high $\mathrm{pH}$, suspended matter, and sulphides that are characteristics of tannery effluent may become injurious to fishes as well as other aquatic life in such water bodies (Ajayi, 1996). The logging of contaminated water in the soil may make oxygen less available as an electron acceptor, thus prompting denitrifying bacteria to reduce available nitrate into gaseous nitrogen which enters the atmosphere with resultant negative effects (Adesemoye et al., 2006). Another environmental consequence of discharging untreated tannery effluents in the environment is that methanogens may produce excessive methane thus contributing to 
greenhouse effect and global warming (Faruk et al., 2005).

In Sokoto metropolis, tanneries are mostly located in the midst of densely populated residential areas, thereby exposing the inhabitants of such areas to obnoxious odour as well as many toxic chemicals and pathogenic microorganisms. The effluents may also get into underground water sources and this may pose a possible health risk to the inhabitants of such areas. Therefore, the objective of this study was to determine the physico-chemical qualities and the microbial content of soil around Tudunwada, Unguwar rogo and Rijiya residential areas that were contaminated with effluents being discharged on a daily basis by tanneries.

\section{MATERIALS AND METHODS \\ Study area}

The study was conducted at the Microbiology laboratory, Faculty of Science, Usmanu Danfodiyo University, Sokoto. Sokoto town has a total population of 669,413 people as projected in the 1991 National population census with a land mass of $364,122 \mathrm{sqkm}$. It lies at a latitude of $13^{\circ} 01^{\prime} \mathrm{N}$ and longitude $51^{\circ} 5^{\prime} \mathrm{E}$ and $350 \mathrm{~m}$ above sea level. It falls under the Sudan-savanna agroecological zone of Nigeria. The climate is characterized by a long dry season with cool dry air during the harmattan from November to February and a hot season from March to May, then followed by a short rainy period from June to September (Davies, 1982).

\section{Sample Collection}

Sample collection was carried out in accordance with the method described by Orji et al. (2006). Soil samples were collected from three different tanneries located at Tudunwada, Unguwar rogo, and Rijiya areas within the Sokoto metropolis. Samples were collected three times in a month at 10 days interval within the months of April June, 2009. All samples were placed in sterile polythene bags and immediately transported to the Microbiology laboratory of the Usmanu Danfodiyo University, Sokoto for processing. For the control, soil samples were collected from Mabera area (an area devoid of tannery activities) in Sokoto metropolis.

\section{Media used}

The media used in this study were Nutrient agar (Fluka Biochemica, Germany), MacConkey agar (Antec), and Sabouraud dextrose agar (Fluka Biochemica, Germany). All the media were prepared and sterilized according to manufacturer's specifications.

\section{Physico-chemical analysis}

The physico-chemical qualities of the soil samples were determined using the methods described by Ademoranti (1996) and Sadiq and Malami (2009). The parameters determined were:

\section{Determination of $\mathbf{p H}$}

This was determined using $\mathrm{pH}$ meter 3015, Jenway, U. K. Ten grams of the soil sample was placed in a beaker, then $10 \mathrm{ml}$ of distilled water was added and the mixture was stirred. It was allowed to stand for 30 minutes. A buffer solution was used to zero the $\mathrm{pH}$ meter. Then the electrode of the $\mathrm{pH}$ meter was inserted into the mixture and the $\mathrm{pH}$ readings were taken.

\section{Determination of temperature}

This was determined at the point of sample collection. This was done by dipping the bulb of mercury-in-glass thermometer into the soil suspension and the readings recorded.

\section{Determination of phosphorus}

This was determined using Vanado-molybdophosphoric acid colometric method using ammonium molybdate which formed molybdophoshoric acid under acidic condition. The intensity of the yellow colour was measured using spectrophotometer at $490 \mathrm{~nm}$.

\section{Determination of sulphide}

This was done by adding $2 \mathrm{~cm} 3$ of concentrated $\mathrm{HCl}$ to $100 \mathrm{~cm} 3$ of the sample and the mixture heated to dryness. The residue was dissolved into $5 \mathrm{~cm} 3$ of concentrated $\mathrm{HCl}$ and the insoluble portion was filtered off and washed with hot distilled water. It was further diluted to $100 \mathrm{~cm} 3$ and adjusted to $\mathrm{pH} 4.5$ using acetate buffer. The mixture was again heated to boiling until the precipitation was completed. The precipitate was digested at $80 \mathrm{oC}$ for 3 hours, filtered, dried and weight to constant weight in a pre-weight 
evaporating dish. Finally the value of sulphide was calculated.

\section{Determination of ammonia}

The ammonium content was determined using the Macro-kjeldahl method (Udo and Ogunwale, 1986). Two grams of the sample was weighed and transferred to an $800 \mathrm{ml}$ kjeldahl flask. Then $2 \mathrm{~g}$ of salt mixture $\left(\mathrm{K}_{2} \mathrm{SO}_{4}: \mathrm{CuSO}_{4} .5 \mathrm{H}_{2} \mathrm{O}\right.$ : Selenium powder) and $30 \mathrm{ml}$ concentrated $\mathrm{H}_{2} \mathrm{SO}_{4}$ were added to the flask and shaken thoroughly to mix completely. The flask was placed on the digestion rack and digested until all the organic matter was destroyed as indicated by the content turning light grey in colour. The flask was then cooled and $50 \mathrm{ml}$ of distilled water was added, shaken properly and cooled.

The flask was mounted on distillation rack and $20 \mathrm{ml}$ of boric acid mixed indicator was pipetted and placed under the still set such that the delivery tube just touched the surface of the solution, and at the same time opening the cooling water tap. $20 \mathrm{ml}$ of $40 \% \mathrm{NaOH}$ solution was added from the side arm to the kjeldahl flask and the distillation started. About $40 \mathrm{ml}$ of distillate was collected and titrated with standard acid solution. The ammonium content was calculated using the formula:

$$
\mathrm{NH}_{3}(\%)=\frac{\mathrm{ml} \mathrm{H}_{2} \mathrm{SO}_{4} \times \text { Normality of acid } \times 0.014}{\text { Weight of the sample }} \times 100
$$

Determination of magnesium and chromium using Atomic absorption spectrophotometry These were determined by preparing various dilutions from 1000ppm of stock solutions of magnesium and chromium (1000ppm). The dilutions were used for the preparation of standard calibration solutions. Then $100 \mathrm{~cm}^{3}$ of the samples were digested with concentrated $\mathrm{HCl}$ and $\mathrm{HNO}_{3}$ in a ratio of $3: 1$, filtered and diluted to $250 \mathrm{~cm}^{3}$ with distilled water. A blank solution was prepared by treating $100 \mathrm{~cm}^{3}$ of distilled water in the same manner. The elements magnesium and chromium were determined by aspirating the standard solutions, samples and blank at $285.2 \mathrm{~nm}$ and $425.4 \mathrm{~nm}$ respectively.

\section{Determination of potassium and calcium by Flame emission spectrophotometry}

These were determined by preparing various dilutions from 1000ppm of stock solutions of potassium and calcium. The diulutions were used for the preparation of the calibration standards. Then the standard solutions, samples and blank were aspirated using a flame photometer with the filters of potassium and calcium

\section{Microbiological analysis}

The microbiological analysis was carried out based on the methods described by Adesemoye et al. (2006), Oyeleke and Manga (2008) and Rabah et al. (2008). A measure of $1 \mathrm{~g}$ of the soil sample collected near the sewers was serially diluted in tenfolds up to $10^{6}$ tubes. Then $0.1 \mathrm{ml}$ aliquots from the $10^{4}$ tubes were aseptically inoculated onto already prepared plates of nutrient agar, macconkey agar and sabouraud dextrose agar using the spread plate method of inoculation. The nutrient agar and macconkey agar plates (for bacteria) were incubated at $37^{\circ} \mathrm{C}$ for 24 hours while the sabouraud dextrose agar plates (for fungi) were incubated at ambient laboratory temperature $\left(28 \pm 2^{\circ} \mathrm{C}\right)$ for 72 hours.

After the incubation period, plates with distinct colonies were counted and recorded as cfu/g. The colonies were also repeatedly subcultured onto fresh nutrient and sabouraud dextrose agar media to obtain pure isolates. The bacterial isolates were identified and characterized using cultural, morphological and standard biochemical tests as described by Cheesebrough (2003). The tests that were employed include Gram stain, motility, catalase, methyl red test, voges-proskaeur test, indole production, urease activity, $\mathrm{H}_{2} \mathrm{~S}$ and gas production, citrate utilization test, glucose, sucrose and lactose utilization tests, oxidase test and spore test. The fungal isolates were identified according to the methods described by Oyeleke and Okusanmi (2008) based on their colour of aerial hyphae and substrate mycelium, arrangement of hyphae, and conidial arrangement.

\section{RESULTS AND DISCUSSION}

The results of the physico-chemical parameters of the soil samples determined were presented in Table 1. From the results, both the $\mathrm{pH}$ (7.2-7.6) and temperature $\left(34^{\circ} \mathrm{C}\right)$ of the samples were within the normal range. This could further 
explain the high counts of microorganisms obtained from all the sampling sites because most microorganisms thrive well as such $\mathrm{pH}$ value. The $\mathrm{pH}$ could also further enhance microbial degradation of the contents of the effluents. The sulphide, ammonia and chromium levels ranged from $0.35-0.44 \mathrm{mg} / \mathrm{g}, \quad 0.44-060 \mathrm{mg} / \mathrm{g}$ and 0.20 $0.26 \mathrm{mg} / \mathrm{g}$ respectively. These levels were high than the limits set by the Federal Ministry of Environment of $0.2 \mathrm{mg} / \mathrm{g}$ of sulphide and ammonia and $<0.1$ for chromium. A possible explanation for the high level of sulphide could be as a result of the use of sulphuric acid or products with high content of sodium sulphate in tanning process. It could also be that $\mathrm{H}_{2} \mathrm{~S}$ was formed in the soil under conditions of oxygen deficiencies as a result of logging of the effluents in the soil. The high level of ammonia may retard the oxidation of nitrite in the soil and may result into accumulation of nitrite in the soil. These results tallied with the works of Dalmau et al. (1989) in which they reported that the application of sewage sludge on soils increased the ammonia content of such soils. In another research, Yusuf and Sonibare (2004) reported a high sulphide and ammonia levels far exceeding the levels set by the Federal Ministry of Environment in textile industries' effluents in Kaduna State, Nigeria. Chromium, a heavy metal was detected in all the soil samples. A possible explanation for its high level is as a result of the use chromium salt for tanning. This could be disastrous to the concept of a clean environment. It may also enter the food chain through plants, animals, as well as water sources. Once it gets into food chains, biomagnifications and bioaccumulation of the metal in various living systems may take place. This result was in conformity with that of Ezeronye and Obalua (2005) in which they reported that bioconcentration and magnification could lead to toxic levels of these metals in organisms even if exposure level is low. This could also cause disruption in the ecological balance when in abundance.

Table 1: Physicochemical qualities of soil contaminated with tannery effluents

\begin{tabular}{lccccc}
\hline Parameters & \multicolumn{5}{c}{ Sampling Sites } \\
& SUR & STW & SRA & SMB & FMEnv Limit \\
\hline $\mathrm{pH}$ & 7.5 & 7.2 & 7.6 & 6.80 & $6-9$ \\
Temperature $\left({ }^{\circ} \mathrm{C}\right)$ & 34 & 34 & 34 & 34 & 40 \\
Phosphorous $(\mathrm{mg} / \mathrm{g})$ & $\mathrm{ND}$ & $\mathrm{ND}$ & $\mathrm{ND}$ & $\mathrm{ND}$ & 5 \\
Potassium $(\mathrm{mg} / \mathrm{g})$ & 0.09 & 2.00 & 1.70 & 0.23 & - \\
Calcium $(\mathrm{mg} / \mathrm{g})$ & 0.10 & 0.20 & 0.10 & 0.1 & 200 \\
Magnesium $(\mathrm{mg} / \mathrm{g})$ & 0.20 & 0.20 & 0.50 & 0.05 & 200 \\
Sulphide $(\mathrm{mg} / \mathrm{g})$ & 0.35 & 0.44 & 0.40 & 0.05 & 0.2 \\
Ammonia $(\mathrm{mg} / \mathrm{g})$ & 0.46 & 0.40 & 0.60 & ND & 0.2 \\
Chromium $(\mathrm{mg} / \mathrm{g})$ & 0.20 & 0.24 & 0.26 & ND & $<0.1$ \\
\hline
\end{tabular}

KEY: SUR- soil from unguwar rogo tannery, STW- Soil from tudun wada tannery, SRA- Soil from rijiya area tannery, and SMB- Soil from mabera area (control), ND- Not detected, ${ }^{\circ} \mathrm{C}$ - degree celsius, $\mathrm{mg} / \mathrm{g}$ - milligramme per gramme. 
The results of the different variety of bacteria isolated from the soil samples were presented in Table 2. From the result, the organisms isolated were Bacillus cereus, Bacillus subtilis, Pseudomonas aeruginosa, Proteus mirabilis, Serratia marcensces, Escherichia coli, Streptococcus pyogenes, Klebsiella pneumoniae. The results of the fungal isolates from the soil samples were presented in Table 3. Based on the results, the isolates were identified as Aspergillus niger, Aspergillus flavus, Aspergillus fumigatus, Penicillium notatum, Mucor pusillus as well as Fusarium sporotrichioides. The results of the viable counts of microorganisms were presented in Table 4. The results revealed that the soil samples contained a high density of both bacterial and fungal flora. Counts in the range of $8.60-8.70$ $\times 10^{5} \mathrm{cfu} / \mathrm{g}$ and $1.70-2.0 \times 10^{4} \mathrm{cfu} / \mathrm{g}$ were recorded for bacteria and fungi respectively. However, fewer counts of microorganisms were recorded from soil samples obtained from the control site. However, statistical analysis of all the parameters tested in the sampling sites using one-way analysis of variance (ANOVA) using
SPSS version (14.0) showed no significant difference between the parameters. Most of the organisms isolated are indigenous to soil environments and their abundance and diversity may be attributable to high tanning activities of the tanneries and the subsequent discharge of their effluents into the surrounding soil, thereby enriching the available nutrients in such soils. It may also be attributable to the destabilization of the soil ecological balance arising from the contamination. These findings agreed well with similar findings reported by Osaro (2002) and Orji et al. (2006) in which they found that organisms of the genera Bacillus, Klebsiella, Pseudomonas, Penicillium, Aspergillus, and Mucor were predominant in soils contaminated with palm oil mill effluents in Benin city (Edo State), and Awka North, Aguata, and Awka South Local Government Areas of Anambra State. Also, Ogbonna and Igbenijie (2006) reported high occurrence and diversity of Proteus sp, Streptococcus sp, Escherichia coli, Fusarium sp, and Aspergillus niger among others in soils of waste collection sites in Port Harcourt city in Rivers State of Nigeria.

Table 2: Cultural, morphological and biochemical characteristics of bacteria isolated from soil contaminated with tannery effluents

\begin{tabular}{|c|c|c|c|c|c|c|c|c|c|c|c|c|c|c|c|c|}
\hline $\begin{array}{l}\text { Colonial } \\
\text { characteristi } \\
\text { cs }\end{array}$ & $\begin{array}{l}\text { Gram } \\
\text { stain }\end{array}$ & Mot & Cat & GI & La & $\mathrm{Su}$ & $\mathbf{H}_{2} \mathbf{S}$ & Ga & $\mathbf{M}$ & VP & Ind & Cit & $\mathbf{O x}$ & $\mathbf{U r}$ & Sp & $\begin{array}{l}\text { Organism } \\
\text { (s) }\end{array}$ \\
\hline $\begin{array}{l}\text { Small milky } \\
\text { white clonies }\end{array}$ & +Rods & + & + & + & - & - & + & - & - & + & - & + & + & + & + & $\begin{array}{l}\text { Bacillus } \\
\text { cereus }\end{array}$ \\
\hline $\begin{array}{l}\text { Large white } \\
\text { colonies }\end{array}$ & +Rods & + & + & + & - & - & + & - & + & - & - & + & - & - & + & $\begin{array}{l}\text { Bacillus } \\
\text { subtilis }\end{array}$ \\
\hline $\begin{array}{l}\text { Large milky } \\
\text { white } \\
\text { colonies }\end{array}$ & $-\operatorname{Rod}$ & + & + & + & - & + & + & + & + & - & - & + & - & + & - & $\begin{array}{l}\text { Proteus } \\
\text { mirabilis }\end{array}$ \\
\hline $\begin{array}{l}\text { Blue-green } \\
\text { colonies }\end{array}$ & $-\operatorname{Rod}$ & + & + & + & - & - & - & - & + & - & - & + & + & - & - & $\begin{array}{l}\text { Pseudomon } \\
\text { as } \\
\text { aeroginosa }\end{array}$ \\
\hline $\begin{array}{l}\text { Large gray } \\
\text { colonies }\end{array}$ & -Rod & - & - & + & + & + & - & + & - & + & - & + & - & + & - & $\begin{array}{l}\text { Klebsiella } \\
\text { pneumonia }\end{array}$ \\
\hline $\begin{array}{l}\text { Small white } \\
\text { colonies }\end{array}$ & $-\operatorname{Rod}$ & + & + & + & + & + & - & + & + & - & + & - & - & - & - & $\begin{array}{l}\text { Escherichi } \\
\text { a coli }\end{array}$ \\
\hline $\begin{array}{l}\text { Large gray } \\
\text { colonies }\end{array}$ & $-\operatorname{Rod}$ & + & + & + & - & + & - & + & - & + & - & + & - & + & - & $\begin{array}{l}\text { Serratia } \\
\text { marcensces }\end{array}$ \\
\hline $\begin{array}{l}\text { Large milky } \\
\text { rhizoid } \\
\text { colonies }\end{array}$ & + Cocci & - & - & + & + & + & - & - & + & - & - & - & - & - & - & $\begin{array}{l}\text { Streptococc } \\
\text { us } \\
\text { pyogenes }\end{array}$ \\
\hline
\end{tabular}


Rabah and Ibrahim; Physico-Chemical and Microbiological Characterization of Soils Laden with Tannery Effluents in Sokoto, Nigeria.

Table 3: Morphological Characteristics of Fungal isolates from soil contaminated with tannery effluents

\begin{tabular}{llll}
\hline Isolate & Macroscopy & Microscopy & Organism(s) \\
\hline TF1 & Black and Powdery - like & $\begin{array}{l}\text { Conidiophores smooth walled and } \\
\text { non septate }\end{array}$ & Aspergillus niger \\
TF2 & Whitish and cottony-like & Round, Black Conidia, non-septate & Mucor pusillus \\
TF3 & Light green and Powdery-like & Long, erect septate conidiophores & Aspergillus flavus \\
TF4 & Brown and cottony-like & $\begin{array}{l}\text { Long, erect conidiophores. Round- } \\
\text { shaped conidia }\end{array}$ & Penicillium notatum \\
TF5 & Gray-green fluffy colonies & $\begin{array}{l}\text { Long erect non-septate } \\
\text { conidiophores }\end{array}$ & $\begin{array}{l}\text { Aspergillus } \\
\text { fumigates }\end{array}$ \\
TF6 & Yellow-pink creamy colonies & $\begin{array}{l}\text { Cylindrical to ovoid conidia, } \\
\text { Curved septateconidiophores }\end{array}$ & $\begin{array}{l}\text { Fusarium } \\
\text { sporotrichioides }\end{array}$ \\
\hline
\end{tabular}

KEY: TF: Tannery fungi

Table 4: Total viable counts of microorganisms isolated from soil contaminated with tannery effluent

\begin{tabular}{lcc}
\hline Sampling site & TBC \pm SD $\left(\times 10^{5} \mathrm{cfu} / \mathrm{g}\right)$ & $\mathrm{TFC} \pm \mathrm{SD}\left(\times 10^{4} \mathrm{cfu} / \mathrm{g}\right)$ \\
\hline SUR & $8.60 \pm 1.80$ & $2.00 \pm 0.10$ \\
STW & $8.70 \pm 0.52$ & $1.83 \pm 0.06$ \\
SRA & $8.65 \pm 0.90$ & $1.70 \pm 0.30$ \\
SMB (Control) & $3.20 \pm 0.12$ & $1.10 \pm 0.07$ \\
\hline
\end{tabular}

Key: TBC- Total bacterial count, TFC- Total fungal count, cfu/g- Colony forming unit per gramme, SUR- soil from unguwar rogo tannery, STW- Soil from tudun wada tannery, SRA- Soil from rijiya area tannery, and SMB- Soil from mabera area (control).

\section{REFERENCES}

Ademoranti, C.M.A. (1996). Standard methods for water effluent analysis. 1st edition, Fokudex Press Ltd, Ibadan, Nigeria, pp 111-117

Adesemoye, A.O., Opere, B.O. and Makinde, S.C.O. (2006). Microbial content of abattoir wastewater and its contaminated soil in Lagos, Nigeria. Afr. J. Biotechnol. 5 (20): 1963-1968.

Ajayi, B. (1996). Industrial pollution control. Wamabod's giant stride magazine, pp 23.

Cheesebrough, M. (2006). District laboratory practice in tropical countries. Part 2. Low Price Edition. Cambridge University Press, London, pp 28-90

Dalmau, J.L.I., Garwi, M.A. and Felipo, M.T. (1989). Laboratory prediction of soluble compounds before soil recycling.
International Journal of Environment and Analytical Chemistry, 39: 141-146

Davies, G. (1982). Rainfall and temperature, Sokoto State in maps. An Atlas of Physical and Human Resources. John Wiley and Sons Inc, New York, pp

Ezeronye, O.U. and Ubalua, A.O. (2005). Studies in the effect of abattoir and industrial effluents on the heavy metals and microbial quality of Aba River in Nigeria. Afr. $J$. Biotechnol. 4(3): 266-272

Faruk, F., Akram, A, Jerzy, D., Mary, A. B., and Jean, M.B. (2005). Physicochemical characteristics of Animal and Animal wastes decomposed in arid soils. J. Environ. Qualities 34: 1392-1403.

Imamulhaqq, S.M. (1998). Critical environmental issues relating to tanning industries in Bangladesh. A paper presented at a 
workshop held at the Tamil Nadu Agiricultural University, Combatore, India, $31^{\text {st }}$ Jan $-4^{\text {th }}$ Feb, 1998, p 65

Ogbonna, D.N., Soker, T.C., and Benson, G.I. (2004). Studies on the bacterial population and inorganic content of waste dump sites in Okrika Local Government area of Rivers State, Nigeria. Nig. J. Environ. Sci. 2(1): 611

Ogbonna, D.N. and Igbenijie, M. (2006). Characteristics of microorganisms associated with waste collection sites in Port Harcourt City, Nigeria. Nig. J. Microbio. 20(3): 1427-1434.

Orji, M.U., Nwokolo, S.O. and Okolo, I. (2006). Effect of palm oil mill effluent on soil microflora. Nig. J. Microbio. 20(2): 10261031.

Osaro, E.F. (2002). Microbiological studies of palm oil mill effluent from NIFOR, near Benin city, Nigeria. Nig. Acad. Forum 2(2): 1-6.

Oyeleke, S.B. and Manga, S.B. (2008). Essentials of Laboratory Practicals In Microbiology. First Edition, Tobest Publishers, Minna, Nigeria, pp 36-67

Oyeleke S.B. and Okusanmi, T.A. (2008). Isolation and Characterization of Cellulose
Hydrolyzing Microorganisms from the Rumen of Ruminants. Afr. J. Biotechnol. 7 (9): 30 .

Rabah, A.B., Ijah, U.J.J., Manga, S.B. and Ibrahim, M.L. (2008). Assessment of Physico-chemical and microbiological qualities of abattoir wastewater in Sokoto, Nigeria. Nig. J. Basic Appl. Sci. 16(2): 145150.

Sadiq, S.I. and Malami, S. (2009). Comparative study of the effects of tannery effluents on two major streams in Sokoto State, Nigeria. Nig. J. Basic Appl. Sci. 17(1): 48-52.

Tudunwada, I.Y., Essiet, E.U. and Muhammad, S G. (2007). The effects of tannery sludge on heavy metals concentration in cereals on small-holder farms in Kano, Nigeria. $J$. Environ. Control 35: 65-69.

Udo, E.J. and Ogunwale, J.A. (1986). Laboratory Manual for the Analysis of Soil, Plant and Water Samples, $2^{\text {nd }}$ Edition. University Press, Nigeria.

Yusuf, R. O. and Sonibare, J. A. (2004). Characterization of textile industries effluents in Kaduna, Nigeria and pollution implications. Global Nest: The Inter. J. 6(3): 212-221. 